\title{
Brazilian design in the 1970s, autonomy in progress
}

The article discusses Brazilian design from the 1970s in terms of its autonomy in relation to core-country projects and introduces some that addressed particularistic issues without rejecting technological advances. It calls for a historiographical revision of the period in terms of not submitting to the exclusive dictates of the international market and shaping an autonomous critical tradition. autonomy, universalism, particularism, design, periphery

We are required to universalize our particulars and particularize our universals simultaneously and in a kind of constant dialectical exchange, which allows us to find new syntheses that are then of course instantly called into question. It is not an easy game.

Immanuel Wallerstein

\section{Introduction}

Two interpretations are often used as explanatory frameworks for design in peripheral or former colonial countries. One sees them as merely reflecting core countries, acting as paler mirror images lagging behind those of the center. The other is based on the idea of specific, genuine, natural or traditional nativity that confers independence to the periphery's production in relation to the center, which Wallerstein (2007) calls essentialist particularism as a way of opposing "scientific" universalism. Thus, we are either reflections of the central metropolises or we have our "own essential soul" that lends us authenticity and therefore settled identity. Here I am opposing both of these very recurrent interpretations in order to emphasize certain aspects of the emergence of Brazilian design that have been able to shape autonomous projects, but in doing so have not eschewed the reality of the so-called world system. As Gui Bonsiepe (2013) stated:

\footnotetext{
"... at the time (1950s and 1960s), Argentina, Brazil, and others had developed design discourse, and subsequently practice and education (1960s and 1970s) that were considerably more consolidated than several European countries. For a Eurocentric vision that perceives historical influences as a one-way flow from center to periphery, this was hardly - or not at all - acceptable..."
}

The period to be examined covers Brazil's military dictatorship (1964-1984), particularly from 1968 to 1980, which was known as "the age of lead" (for an intellectual minority and for workers) or the "golden years" (for the urban middle layers and the technocracy). A booming economy and burgeoning state apparatus came with accelerated urbanization 
and industrialization. The 1970 saw major infrastructure projects, especially in electricity, nuclear power, transportation, steel, and large-scale construction under the 2nd National Development Plan (1974-1979). This was the first time design was mentioned in a government program. Few researchers have addressed this period from a design point of view, although many initiatives have pointed to issues involving autonomy and at the same time, technical and cultural aggiornamento in relation to the core countries. By 1969, the 1961 Alliance for Progress program 1 had come to an end. For the United States and its allies, the key threat in Latin America was now socialism, especially in the wake of the Cuban Revolution, together with the spread of civil-society movements from 1968 onwards, including many within the United States itself.

The top international companies had already established subsidiaries in Brazil and the middle classes took on a much weightier role in terms of power and consumer spending. Industrial design was surely to be the way of strengthening the American way of life, with its emphasis on domestic space, domestication of the life of civil-society, and ubiquitous household consumer goods, appliances especially - but furniture too. (LEON, 2013). Therein lay the promise of democratizing consumption combined with the war against inequality under the ideology established by American post-war doctrines that spread in Europe too ${ }^{2}$.

By 1968, as so-called youth demonstrations broke out in many parts of the world, the first class was about to graduate from Rio de Janeiro's Escola Superior de Desenho Industrial (ESDI) [industrial design school] founded in 1963 and modeled on the Ulm school in Germany. Although students in Brazil broadly followed the same libertarian guidelines as the May 68 movement in France, they had their own specific demands chiefly arising from the struggle against the 1964 military dictatorship and its blocking advances in terms of democracy and social justice that had been gestating in the previous period. Rio de Janeiro's Museu de Arte Moderna [modern art museum] planned an Industrial Design Biennial with guests from the United States, Canada and England. While the São Paulo Art Biennial was beset by crisis and clashes with the military dictatorship, this was out of the question for the holders of the Industrial Design Biennial, which was supposed to be neutral ground. Who would see refrigerators, stoves, household utensils or office chairs and institutional brands as grounds for political conflict? This role was set aside for art and artists as the Establishment's enfants terribles. Designers were supposed to be allies of industry, rationalized manufacturing, and emblems of capitalist business.

1). An installation posed a corrosive critique of consumer society and the American way of life. An autonomous approach clashed with the mainstream international design posed by the museum's board and rejected the course defined as gute Form by so many UIm graduates and other modernist practitioners. Critical questions were raised. For what and for whom were these multifarious objects being made? What was a vacuum cleaner for in a peripheral country with an abundant low-cost workforce using brushes? Such were

\footnotetext{
${ }^{1}$ A kind of Marshall Plan launched by Kennedy in 1961 giving US $\$ 20$ billion in aid for the poor of the continent. Azevedo (2008:132) writes that the Kennedy administration sought to persuade. Congress that technology transfer and financial aid would end backwardness in Latin America. This assistance was be given "on the lines of the Protestant philanthropic tradition that the Rockefeller family always sought to embody."

² Betts (2004:144) thus explains U.S. funding for the Ulm school. In Brazil, growth in this period only increased inequalities; as economics minister Delfim Neto noted, "first make a bigger pie; then we can distribute it."
} 
the outlines of ideas taken up by theorists such as Victor Papanek and found in the First Things First manifesto. Their critique of consumer society was posed without replicating the theoretical-political production of the core countries while establishing particularities for Brazil. Talking to A. Nobre (1990:130), former student Maria Valderez da Paz made this comment $^{3}$

"The ESDI stand discussed the meaning of design, what design meant in Brazil and for Brazil. Among other things, we wanted the school to turn toward the real situation in Brazil. "

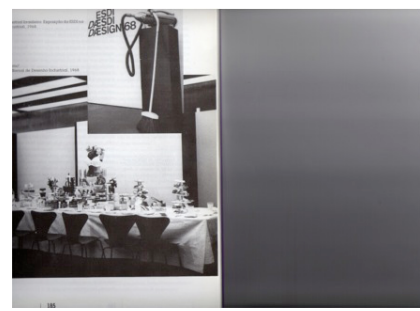

\section{Design promoted by the State: the struggle against peripheral condition}

This generation (comprising architects / designers from Universidade de São Paulo) was responsible for high-complexity strategic projects executed in the 1970s, while the economy was growing at 10\% annually under the military dictatorship.

The military governements have been promoting what was called by many authors an 'authoritarian modernisation' (IANNI, 1979) of the country. To achieve this purpose, they invested in scientific-technological institutions with the purpose of producing nuclear energy and an industrial infrastructure (MOTOYAMA, 320-385). They also aimed to replace imported produtcs by producing consumer goods of all kinds in the country. It was due to this politics that design entered in strategic plans.

Since the 1968 Biennial, it can be observed the relationship between design and government actions. For instance,the PVDI studio was showing designs for new banknotes that for the first time were printed in Brazil rather than the UK. The developing government strategies (which antecede military governments but still remained) allowed small and medium-sizes companies of consumer goods to establish design as a routine, which, in some cases, shows autonomy and not copy practices. Since the 50's Michel Arnoult, a designer born in France but holding a degree in Architecture from Brazil, presented the furniture kits of his own company, Mobília Contemporânea (Contemporary Furniture), a proposal that would later be developed by Terence Conran in Britain. José Carlos Bornancini and Nelson Petzold showed their Wallig Nordeste stove, scaled and designed for low-cost manufacture to target the consumer market in northeastern Brazil (where poorness was worse than in the whole country) where the average height of users was well below that of North-Americans or Europeans.

Three Design Biennials were held, the last in 1972. Subsequently the Instituto de Desenho Industrial [industrial design institute] was set up as part of the modern art museum to
Figure 1.

O Banquete do Consumo [consumer banquet]. Source: SOUZA, P.de. ESDI, biografia de uma ideia.(1996) Rio de Janeiro: UERJ, p. 185. 
theme 3

identity

Figure 2.

PEG -LEV armchair by Michel Arnoult, sold in kit form, Author's archive.

Figure 3. Curitiba's "domes", designed by Abrão Assad strand 2

localities / globalities

execute direct government commissions and develop projects for strategic areas of Brazil, including standards for school furniture and recommendations for export packaging. Rather than being designed for mass production, school furniture was supposed to be made by low-tech firms on a decentralized basis all over Brazil. Several pieces of furniture for rural schools reflected specific habits such as sitting closer to the ground (MAM / RJ / RDI, 1978). They rejected the notion of following a pattern seen as universalist, both in terms of recognizing that furniture would be made by small workshops and from the point of view of users: not taking one generic student size for anthropometric parameters (for the various stages of school life), but reflecting different bodily habits. There was adherence to modern principles of rationalization, but no adoption of universalizing (i.e. Western European) standards for manufacturing or using objects. This project shows the high level in research for a design and producing autonomy, which was only possible by the State's order.

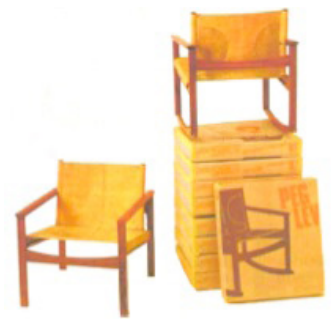

\section{Design in strategic projects: the search for autonomy}

During this period, federal government backed heavy investment in technologically advanced areas that are rarely highlighted in the historiography of design. Designers were enlisted to work on strategic projects for Brazil, such as Embraer, the statecontrolled manufacturer of military and passenger aircraft as well as the Ipanema crop sprayer. An industrial design team was set up to work with engineers on sugar-cane and cassava harvesters for the strategic interest of sourcing alternatives to petroleum 4 . Rapid urbanization prompted government investment in subways in São Paulo and Rio de Janeiro, the two biggest cities, with designers playing a decisive role not only in visual identity and signage, but also trains, seating arrangements, station control consoles and ticket offices (LEON, 2005). In the 1970s, again, designers made key interventions in major urban government's projects for Curitiba's downtown shopping area and São Paulo's financial district. Materials such as acrylic (figure 2) were used as covering for pedestrian streets. In reformulating the financial center, fiberglass was used for bus shelters and other equipment (LEON, 2009).

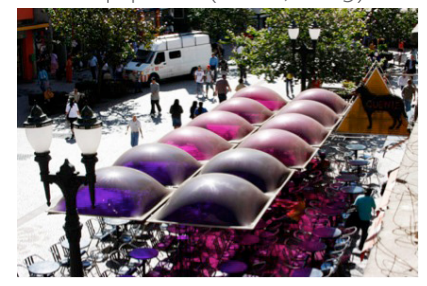

${ }_{4}^{4}$ The 1973 'oil crisis' was subsequently seen as a marker for the transition from the Fordist period to flexible accumulation, as shown by HARVEY (1992:136). There was concern over the effects of the international oil cartel for Western economies. Brazil developed several technologies using alternative fuels, including alcohol. 
The federal government's information technology policy showed the scale of its ambitions. (MELO, 1982). A new commission for coordinating electronic processing activities was attached to the Presidential Planning Department and it introduced a protected market for mini- and micro-computers in 1976. Protection was subsequently extended to process control equipment; "super-mini-computers"; numerical control machines; semiconductors and instrumentation; CADs and industrial robots. As a result of this protectionist policy, new computing companies were set up to develop Brazilian hardware and software. Equipment designed locally by Prológica and others included banking automation technology and subsequently ATMs. These projects were developed with Brazilian industrial designers who could only work in these such areas because of the government policies of technological autonomous development.

Despite this wide range of projects, many of great complexity and outreach socially, there was not yet the capability to demarcate a specific tradition for Brazilian design.5 This period was followed by economic stagnation in the 1980 , referred to locally as "the lost decade", while growing numbers of design graduate who could not count on the government programs of the anterior period were occupied with corporate identity and packaging for major manufacturers, or making hardwood furniture mostly for elite customers, or were employed by multinationals. However, it would be wrong to ignore this history of criticizing the production of gadgets in core countries or the extensive attempts to respond to local demands autonomously: to do so would be to fall into the trap of the saturated market's absolutist "there is no alternative", or neo-liberal intellectual orthodoxy. In 1970 s Brazil, design showed its ability to take on complex projects with a significant role in the daily lives of the majority in a way of struggling the periphery condition.

\section{Conclusion}

Any attempt to interpret design produced in this period, taking into account the heteronomy of design activities for the market or communities or government plans, must be simultaneously local and international, as shown by Roberto Schwarz (2012: 165-172). An international approach alone would focus exclusively on projects identified with the ideas and modus operandi of certain social groups in core countries. A local focus would mean ignoring anything that had in some way benefited from technical progress in core countries. Domestic production both showed particularities and at the same time was an expression of the global economic order, since peripheries are always part of this system. Examining this past does not mean falling into anachronistic patriotism, but fighting a tendency to portray periphery countries as inferior to core actors. In some cases, it means realizing that work done under tight financial and material constraints was capable of producing elements that would be considered environmentally friendly some years later. However this would provide the subject matter for another article.

\section{References}

AZEVEDO, C. (2008) Em nome da América. Os Corpos de Paz no Brasil. São Paulo: Alameda. BETTS, P. (2004)The authority of everyday objects: a cultural history of West German

\footnotetext{
${ }_{5}^{5}$ The notion of the need to build a tradition relates to the ideas of the literary theorist CÂNDIDO, A. (1981), or forming an autonomous field as in BOURDIEU, Pierre (2005:99).

Of course Brazil's elites have always favored importing anything that meant convenience and pursuit of profitable activities. However, they have always denounced social rights established in central countries as contrary to genuine national customs.
} 
industrial design. Berkeley; Los Angeles: University of California Press.

BONSIEPE, G. (2013)The Centre Periphery Antinomies of Design. Paper submitted to ICDHS conference, Ahmedabad.

BOURDIEU, P.(1974) A economia das trocas simbólicas, 6th edition, São Paulo: Perspectiva. CÂNDIDO, A. (1959). Formação da literatura brasileira: momentos decisivos, 8th ed, BH RJ: Itatiaia

LEON, E. and MONTORE, M.(2008) 'Brasil', in FERNANDEZ, S. and BONSIEPE, G (eds)., Historia del Diseño en América Latina y el Caribe. São Paulo: Blucher. HARVEY, D.(1992) A condição pós-moderna,18th edition, São Paulo: Loyola. IANNI, Octávio. Estado e planejamento no Brasil. Rio de Janeiro: Civilização brasileira, 1979. LEON, E (2005) Design brasileiro quem fez quem faz. Rio de Janeiro: SENAC/VMosley. . (2009) Memórias do design brasileiro. São Paulo: SENAC. (2013). Design em exposição. Tese de doutoramento. São Paulo: FAU-USP, 2013. MELO, J. C.(1982) A incrível política nacional de informática. Rio de Janeiro: Edição do Autor. MOTOYAMA, S. Prelúdio para uma história. Ciência e Tecnologia no Brasil. São Paulo: Edusp/Fapesp, 2004

MUSEU DE ARTE MODERNA DO RIO DE JANEIRO. Instituto de Desenho Industrial. (1978). Rio de Janeiro.

NOBRE, A. L. (1999) Carmen Portinho. Rio de Janeiro: Relume Dumará. SCHWARZ, R. (2012) "Por que ideias fora do lugar" in Martinha versus Lucrécia. São Paulo: Companhia das Letras.

WALLERSTEIN, I. (2007) O universalismo europeu. A retórica do poder. São Paulo: Boitempo. [European Universalism: The Rhetoric of Power. 2006, 48-49] 